\title{
THE LATEST TRENDS OF ANNULMENT OF THE COMMERCIAL ARBITRATION AWARDS IN UKRAINE: GROUNDS, APPROACHES, CONSEQUENCES
}

\section{Yuliya Kabrera}

\section{INTRODUCTION}

The history of arbitration nascence reaches the millennia. There is an opinion that the arbitration arose together with appearing of the trade relations, which in turn, off course, leads to dispute-resolution issues, and the main guarantee of successful trade provides settlement of such disputes in a peaceful way. A qualitative litigation method - international arbitration arose already in the Ancient World, in order to resolve controversies between medieval merchants in marketplaces in Europe and Mediterranean and Baltic sea trade. The intense usage of commercial arbitration became achievable only after it acquired a modern look and legal backing in The English Arbitration Act 1889. This act actually meant that Courts were empowered to enforce parties' agreement to arbitrate and established basic foundations of arbitration: voluntary participation in arbitration, the right of all citizens who have signed the contracts to court, as well as the arbitration rules. It was later adopted by arbitration statutes in most countries of the British Commonwealth ${ }^{1}$.

The pace of development of international relations is gradually accelerating, globalizing and unifying. Interaction with a foreign element is a big integral part of our lives. With the growth of international trade, the demand for the settlement of international commercial disputes is directly proportional. The main purpose of commercial arbitration is to resolve disputes between the parties on the basis of substantive rules of substantive law, on foreign trade contracts, misunderstandings arising in the process of cooperation, companies of different nationalities and states in any specific legal relationship. There is an extremely high demand for commercial dispute resolution through international arbitration tribunals around the world, generated by the efficiency of arbitration proceedings.

It is worth mentioning that positive and favorable to arbitration court practice is in an overwhelming majority in Ukraine. The author, however,

\footnotetext{
${ }^{1}$ Sait of electronic encyclopedia "The new Encyclopedia Britannica" [Sait of encyclopedia "The new Encyclopedia Britannica"]. britannica.com. Retrieved from https://www.britannica.com/topic/arbitration [in English].
} 
does not aim to cover it, but rather draft the attention to some peculiarities that might be a challenge for potential recognition and enforcement. With this deep analyzes of the Ukrainian legal practice and set aside arbitration awards for the last few years, we can determine trends, directions, or special traits/features of the Ukrainian legal system. In this way we will have a full picture of how the Ukrainian system works and what obstacles lawyers and parties of the dispute can face. International arbitration rules, mixed with the Ukrainian national ones, can create a coherent hybrid whose functional existence, in the author's view, is impractical and fictitious, since it is inconsistent with generally accepted norms of international arbitration practice.

Knowing such debatable special features (that are used for the annulment of the arbitral awards in Ukraine) of the Ukrainian legal machine in advance, and deep understanding of their effects and consequences on both: setting aside the award and legal arbitration practice in general, we can prevent all possible options for the abolition of arbitral awards of a controversial, ambiguous and unreliable nature and, which is even more important, to set a vector of a neutral, predictable, fruitful and resultative justice in Ukraine.

The main grounds for the cancellation of arbitral awards and for the refusal to recognize and enforce them are enshrined in transnational and national laws. The New York Convention of 1958 (hereinafter - the NY Convention), whereto 159 states are parties, including Ukraine since $1960^{2}$, seeks to unify general approaches to recognition and enforcement of arbitral awards and establishes the main reasons for setting aside, refusal to recognize and enforce arbitral awards in the countries that have ratified the convention. Grounds for cancellation and refusal of recognition were also reflected word by word in Art. 459 of the Code of Civil Procedure of Ukraine (hereinafter the CPC of Ukraine) $)^{3}$ and in Art. 34, 36 of the Law of Ukraine "On International Commercial Arbitration" (hereinafter - the ICA Act) ${ }^{4}$ created on the basis of the UNCITRAL Model Law. The analysis of the current court practice over the past few years will be based on the provisions of Art. 5 of the NY Convention.

2 Convention "On the Recognition and Enforcement of Foreign Arbitral Awards" [Convention "On the Recognition and Enforcement of Foreign Arbitral Awards"] (n.d.) newyorkconvention.org. Retrieved from http://www.newyorkconvention.org/list+of+ contracting+states [in English].

3 Tsyvilnyi protsesualnyi kodeks Ukrainy [Ukrainian Code of Civil Procedure] (n.d.) kodeksy.com.ua. Retrieved from https://kodeksy.com.ua/tsivil_nij_protsesual_nij_kodeks_ ukraini/459.htm [in Ukrainian].

${ }^{4}$ Zakon Ukrainy "Pro mizhnarodnyi komertsiinyi arbitrazh" [The Law of Ukraine "On

International Commercial Arbitration"]. (n.d.) zakon.rada.gov.ua Retrived from https://zakon.rada.gov.ua/laws/show/4002-12 [in Ukrainian]. 


\section{The arbitration agreement is not valid under the law to which the parties have subjected it}

This was the ground for setting aside the award in LG Electronics Ukraine $v$ Ant Yapi $^{5}$, considered by the Supreme Court. Two companies, LG Electronics Ukraine and Ukrnekstpulbrut, concluded a contract for the sale of goods whereunder Ukrnekstpulbrut purchased goods and undertook to pay their cost. The contract contained an arbitration clause.

Ant Yapi firm provided security for due performance by Ukrnekstpulbrut of its payment obligation under the contract in favor of LG Electronics Ukraine. Ant Yapi and LG Electronics Ukraine (the creditor) entered into a suretyship agreement, according to the terms of which the guarantor, Ant Yapi, took on a commitment to bear the full responsibility of Ukrnekstpulbrut (the debtor) to the creditor for all obligations under the sale contract concluded earlier. Also, the parties had an additional agreement to the suretyship agreement, which contained the arbitration clause.

Ukrnekstpulbrut failed to perform its payment obligation and LG Electronics Ukraine filed claims against both the principal debtor and the surety with the International Commercial Arbitration Court at the Ukrainian Chamber of Commerce and Industry (hereinafter - the ICAC at the UCCI). The dispute was subjected to the Ukrainian law, which had been chosen by the parties. At some point, LG Electronics Ukraine requested the tribunal to direct all its claims only to Ant Yapi rather than to Ukrnekstpulbrut. The ICAC at the UCCI terminated proceedings against Ukrnekstpulbrut and ultimately monetary claims against Ant Yapi were granted.

Being unsatisfied with the final award, Ant Yapi wanted to set it aside in the competent Court of Ukraine. Ant Yapi emphasized that the additional agreement to the suretyship agreement, which contained the arbitration clause, was concluded in English and Russian with the latter prevailing in case of discrepancies. At the same time, only English (namely non-prevailing) version of the agreement was duly signed by the parties. On that ground, Ant Yapi requested the Court to find that the arbitration clause was invalid since the prevailing version of it was not signed by the parties. Ukrainian Court considered the matter and set aside the final award, reasoning that the arbitration Court did not have the competence to consider the dispute, because there was no actual arbitral agreement between the parties.

5 Sprava "LG Electronics Ukraine v Ant Yapi Sanayi Ve Ticaret Anonim Shirketi no. 761/605/17-ц" [Case LG Electronic Ukraine v Ant Yapi Sanayi Ve Ticaret Anonim Shirketi № 761/605/17-ц]. (n.d.). reyestr.court.gov.ua. Retrieved from http://www.reyestr.court.gov.ua/ Review/70416292 [in Ukrainian]. 
Such decision was based on Art. 547 of the Civil Code of Ukraine (hereinafter - the CC of Ukraine), according to which a juridical act to secure the fulfillment of an obligation must be made in writing and juridical act is null and void if it is not made in written form. In accordance with Art. 207 (2) of the CC of Ukraine, a juridical act is considered to be done in writing, if it is signed by the party (parties). Also, in accordance with Art. 215 of the CC of Ukraine, it is necessary for the local Courts to distinguish types of invalidity of juridic acts: void acts - if their invalidity is established by law (and there is no need in recognition or proof of this fact in a Court) and disputed acts - if their nullity is not directly established by law, but one of the parties or other interested person denies their validity on the grounds established by law ${ }^{6}$.

So, the logic of the Court meant that the juridic act was null and void because of its non-compliance with the requirements of the law. In our case, the written form is the requirement of the Ukrainian law and this written form means signed agreement. The Russian variant (prevailing version) of the additional agreement to the suretyship agreement was not signed, so, in the Court's opinion, it was not made in written form. Hence, the additional agreement to the suretyship agreement was null and void and thus, there was no actual arbitration agreement between the parties.

One more document was used in The Court's reasoning - The Resolution № 12 of the Plenum of the Supreme Court of Ukraine of 24 December 1999 "On practice of consideration by courts of motions for recognition and enforcement of foreign courts' awards and arbitral tribunals' awards and on annulment of awards rendered by international commercial arbitration courts in the territory of Ukraine" (hereinafter - the Resolution № 12). According to Art. 20 of the Resolution № 12, only on the condition that if the parties have, in a written contract or arbitration clause, manifested their agreed will to resolve their disputes in arbitration tribunal, the court may consider that the arbitration tribunal has competence ${ }^{7}$.

Virtually, in our opinion, it looks as if the Court of Ukraine, construed this resolution № 12 in it’s own very specific way, which means that if the parties

${ }^{6}$ Tsyvilnyi kodeks Ukrainy [The Civil Code of Ukraine]. (n.d.). zakon.rada.gov.ua. Retrived from https://zakon.rada.gov.ua/laws/show/435-15 [in Ukrainian].

${ }^{7}$ Postanova no. 12 Plenum verkhovnoho sudu Ukrainy "Pro praktyku rozghliadu sudamy klopotan pro vyznannia y vykonannia rishen inozemnykh sudiv ta arbitrazhiv i pro skasuvannia rishen, postanovlenykh u poriadku mizhnarodnoho komertsiinoho arbitrazhu na terytorii Ukrainy" [The Resolution no. 12 of the Plenum of the Supreme Court of Ukraine "On practice of consideration by courts of motions for recognition and enforcement of foreign courts' awards and arbitral tribunals' awards and on annulment of awards rendered by international commercial arbitration courts in the territory of Ukraine"]. (n.d.) zakon.rada.gov.ua Retrived from https://zakon.rada.gov.ua/laws/show/v0012700-99 [in Ukrainian]. 
have not concluded an arbitration agreement in writing, no arbitral tribunal has the legitimacy to arbitrate their case at all.

Eo ipso, the Court ruled that there was a legal relationship between two companies on the grounds of a suretyship agreement, which by its legal nature was a juridical act to secure the performance of the obligation and, therefore, had to be in writing. The court reasoned that if the additional agreement was not in writing, it was null and void and, hence, the arbitral tribunal did not have legitimacy and thus, the competence to resolve the dispute.

In our opinion, this annulment looks very controversial and generates lots of questions for further discussion. Firstly, the approach used by the Court to set aside the award in the above mentioned case contradicts the Ukrainian legislation itself in three aspects.

The first is, because of the Art. 218 (2) of the CC of Ukraine which has the provision that if the juridical act, for which the law establishes its invalidity in case of non-compliance with the written form, has been concluded verbally and one of the parties has performed an action and the other party has confirmed it, in particular, by the way of acceptance of its enforcement, such a juridical act in case of a dispute can be recognized by the court as valid ${ }^{88}$. So, in this way, I can assume, that the failure to comply with a simple written form of the juridical act does not entail the invalidity of the latter, but only complicates the proof of its existence.

The second aspect is that Ukraine, like most countries, adheres to the principle of "competence - competence" and enshrines this principle in Art. 16 (1) of the Law of Ukraine "On ICA" . The basic provision of the "competence - competence" principle is that the judges of the arbitral tribunal is authorized or has the competence to decide by themselves on the validity of the arbitration clause from which it extracts its prerogative power to resolve the dispute ${ }^{10}$. Therefore, I consider resolving issues about the competence of the arbitral tribunal is out of the jurisdictional sphere of the state Ukrainian Courts at all.

And the third, in our vision, this Court's decision denies the existence of "separability" concept. That means, if the arbitration tribunal thinks that the

${ }^{8}$ Tsyvilnyi kodeks Ukrainy [The Civil Code of Ukraine]. (n.d.) zakon.rada.gov.ua Retrived from https://zakon1.rada.gov.ua/laws/show/435-15/ed20120618 [in Ukrainian].

9 Zakon Ukrainy "Pro mizhnarodnyi komertsiinyi arbitrazh" [The Law of Ukraine "On International Commercial Arbitration"]. (n.d.) zakon.rada.gov.ua Retrived from https://zakon.rada.gov.ua/laws/show/4002-12 [in Ukrainian].

${ }^{10}$ Phillip Landolt, The Inconvenience of Principle: Separability and Kompetenz-Kompetenz (2013) [The Inconvenience of Principle: Separability and Kompetez-Kompetenz] Journal of International Arbitration, (Vols 30), (pp. 511-530). The Netherlands: Kluwer Law International BV [in English]. 
contract which includes the arbitration clause is invalid, it can still rule on its own jurisdiction and decide the dispute under the invalid contract ${ }^{11}$. This idea comes from the notion of the "separability" of the arbitration agreement from the main contract Art. 16 (1) Model Law and Article 16 (1) of the Law of Ukraine "On ICA", an arbitration clause which is an integral part of a contract shall be treated as an independent agreement. The decision by the arbitral court that the contract is null and void shall not entail ipso iure the invalidity of the arbitration clause ${ }^{12}$.

The matter of arbitration agreement validity was also raised in Naumann Machyny i Pallety v Bruma case ${ }^{13}$. Naumann Machyny i Pallety and Bruma entered into an investment contract, which concerned transfer of equipment. The investment contract provided for resolution of all disputes thereunder by the German Arbitration Institute (the DIS). When the dispute arose, Naumann Machyny i Pallety filed claims with the DIS requesting that the equipment is returned and damages are paid.

Before the final award in the case was rendered, Naumann Machyny i Pallety requested that the tribunal imposes interim measures upon Bruma to limit its capacity to dissipate assets. The interim measures were granted and Naumann Machyny i Pallety moved to enforce them at the place of residence of the debtor. At the recognition and enforcement stage Bruma denied validity of DIS arbitration agreement having submitted to the court a written addendum to the main contract, according to which all disputes had to be resolved by the ICAC at the UCCI.

The Ukrainian courts considered the matter and ruled that DIS did not have jurisdiction to consider the dispute They ruled, furthermore, that such a dispute cannot be considered by either the arbitral tribunal at the place where the plaintiff is located, nor by the ICAC at the UCCI, as it is impossible to give preference to one or another body for consideration of the dispute. Under such circumstances, the courts opined, the arbitration agreement cannot be performed and the dispute mentioned above should be considered by the state

${ }^{11}$ Ronán Feehily, (2018). Separability in international commercial arbitration; confluence, conflict and the appropriate limitations in the development and application of the doctrine [Separability in international commercial arbitration; confluence, conflict and the appropriate limitations in the development and application of the doctrine] Arbitration International, 34. Retrived from https://academic.oup.com/arbitration/article-abstract/34/3/355/5098414 [in English].

${ }^{12}$ The UNCITRAL Model Law [The UNCITRAL Model Law]. (n.d.) uncitral.un.org. Retrived from https://uncitral.un.org/en/texts/arbitration/modellaw/commercial_arbitration [in English].

${ }^{13}$ Sprava "Naumann Machyny i Pallety v Bruma № no. 159/4966/15-ц " [ Case Naumann Machyny i Pallety v Bruma № no. 159/4966/15-ц ] (n.d.). reyestr.court.gov.ua. Retrieved from http://www.reyestr.court.gov.ua/Review/63323683 [in Ukrainian]. 
court at the place of residence of the respondent and there was no other legal way out of this situation.

\section{The party against whom the award is invoked was not given proper notice of the appointment of the arbitrator or of the arbitration proceedings and was otherwise unable to present his case}

The proper notice issue is usually invoked at the setting aside and enforcement stages and court practice shows that this ground may be one of the most successful given the Ukrainian court being rather formalistic in their approaches. One of the cases concerned recognition and enforcement of a DIS award for interim measures in support of the pending arbitral proceedings in Naumann Machyny $i$ Pallety $v$ Bruma case already considered in section I above.

Besides, the double inconsistent arbitration clause issue, Bruma also claimed that it was not duly notified of the arbitral proceedings. In particular, in the present case the documents were send per registered post, however it was impossible to establish who was the sender of the notification (the letter bore no reference to DIS, case number etc).

Naumann Machyny i Pallety insisted that the notification originated form one of the arbitrators however could not provide satisfactory proof to support its position. Having considered the matter, the courts ruled that postal dispatch, however per registered e-mail, has to be sent by the institution or an authorized official to be considered a due notification.

Another case, in which due notification was considered by the court, concerned enforcement of LCIA arbitral award in Sea Emerald S.A. v Sudnobudivny zavod imeni 61 comunara case ${ }^{14}$. By concluding a contract for execution of construction works and sale of a refrigerator vessel, the parties agreed that any disputes arising within the scope of that contract shall be submitted to arbitration and would be governed by the law of England and LMAA Rules. The contract provided that all notifications and communications between the parties would be made per post to specified postal addresses. The arbitration clause included parties' phone numbers and faxes, but not e-mail addresses.

The procedure for considering arbitration disputes in England is governed by The Arbitration Act 1996 (hereinafter - The Law). In accordance with paragraph 76 (1) of The Law, the parties are free to agree on the method of

14 Sprava "Sea Emerald S.A. V Sudnobudivny zavod imeni 61 comunara case no. 1423/15646/2012" [Case Sea Emerald S.A. v Sudnobudivny zavod imeni 61 comunara no. 1423/15646/2012]. (n.d.). reyestr.court.gov.ua. Retrieved from http://www.reyestr.court.gov.ua/ Review/62203095 [in Ukrainian]. 
delivery of notices and other documents ${ }^{15}$. Thus, the laws of England provide for the right of the parties to decide on the method of delivering documents.

The Supreme Court of Ukraine came to the conclusion that in determining whether the notification was properly made the Court had to proceed from the relevant procedures specified by the parties in the arbitration clause. By prior agreement on the method of delivery of the documents, the parties did not foresee the use of electronic notifications and there were no e-mail addresses of Sea Emerald S.A. and Sudnobudivny zavod imeni 61 comunara specified in the contract. Such a method of documents delivery or other notices that was not agreed by the parties in the contract could not be considered appropriate and, therefore, the recognition and enforcement of the arbitral award was denied.

\section{The composition of the arbitral authority or the arbitral procedure was not in accordance with the agreement of the parties, or, failing such an agreement, was not in accordance with the law of the country where the arbitration took place}

The issue of the tribunal composition arose between Nussed Serbia d.o.o. $v$ Kompaniia RAIZ case $^{16}$ when in the submission of a dispute for consideration to ICAC at the UCCI each party independently chose the same person to act as an arbitrator, while the contract signed between the parties provided for all disputes thereunder to be considered by two arbitrators under the ICAC at the UCCI Rules $^{17}$. In such circumstances, the President of the ICAC at the UCCI, despite the arbitration agreement between the participants in the dispute, decided that the case had to be considered by the sole arbitrator instead of two.

Having received an unfavorable decision, the respondent in the case referred to a domestic Court to set aside the award because the arbitral tribunal was formed in violation of the parties' agreement. The Ukrainian Court considered the matter and ruled that two arbitrators were foreseen and the parties did not change the terms of the contract by choosing the same person but only chose an arbitrator, one from each side, without knowing that they had chosen the same person. Ukrainian Court grounded its decision stating that the ICAC chairman did not have any legal power to make changes in the quantitative composition of the court by his own decision contrary to the provisions of the arbitration clause. On the contrary, he had to propose to both parties of the process a candidacy of the second arbitrator.

${ }^{15}$ The Arbitration Act 1996 [The Arbitration Act 1996]. (n.d.). legislation.gov.uk. Retrived from https://www.legislation.gov.uk/ukpga/1996/23/section/76 [in English].

${ }^{16}$ Sprava "Nussed Serbia d.o.o. v Rise Company case no. 761/5425/16-ц" [ Case Nussed Serbia d.o.o. v Rise Company case no. 761/5425/16-ц ]. (n.d.). reyestr.court.gov.ua. Retrieved from http://www.reyestr.court.gov.ua/Review/71534619 [in Ukrainian].

17 The ICAC at the UCCI Rules 2018 [The ICAC at the UCCI Rules 2018]. (n.d.). icac.org.ua Retrived from https://icac.org.ua/en/arbitrazh/reglament/ [in English]. 
Plea of Nussed Serbia d.o.o. that Kompaniia RAIZ waived its right to object because the latter continued participating in the arbitration proceedings without objecting to the change of the arbitrator, was the subject matter of investigation of a cassation Court. However, the Court did not accept such arguments of the party as proper.

In my opinion, cancellation of the award in the case described above looks rather doubtful because one of the basic principles of the Model Law is bona fides, fairness in the use of procedural rights vested in the parties. The manifestation of this principle is the waiver of the right to object by virtue of Art. 4 of the Model Law and Art. 4 of the Law of Ukraine "On ICA". According to those articles, a sanction is imposed on the party who did not use the time reasonably given to it for raising objections under certain conditions, namely on the basis of general principles such as estoppel or venire contra factum proprium (to act against one's own previous conduct $)^{18}$. That means that the party was given a special period of time for raising any objections, but if this party did not use its own right to object during the time given to it and proceeded with the arbitration, such party will be precluded from raising any objections or invoking the non-compliance as a ground for setting aside the award, or from using objections as a reason for refusing to recognize and enforce the award after it had been rendered, as it was vividly interpreted in analytical commentary to Art. 4 on draft Model Law on international commercial arbitration ${ }^{19}$.

Similar issue of tribunal composition arose in SES Astra ABv Ukrkosmos $\operatorname{case}^{20}$. A contract between SES Astra AB and Ukrkosmos contained arbitral agreement according to which any disputes must be resolved by a panel of three arbitrators under the Rules of ICC. When the arbitral proceedings were commenced, SES Astra AB suggested to the Secretariat that the dispute is considered by the sole arbitrator. The Secretariat notified the matter to Ukrkosmos. Ukrkosmos in its reply to SES Astra AB suggestion stated that it would not object to the case being submitted to the sole arbitrator provided that the two parties would manage to agree upon its candidacy. Apparently, no agreement was reached between the parties, but the Secretariat nevertheless submitted the case to the sole arbitrator.

${ }^{18}$ Reinhold, Steven, Good Faith in International Law (2013). [Good Faith in International Law] Journal of Law and Jurisprudence, 2. Retrived from https://ssrn.com/abstract=2269746 [in English].

19 Analytical Commentary on Draft Text of a Model Law on International Commercial Arbitration A/CN.9/264 [Analytical Commentary on Draft Text of a Model Law on International Commercial Arbitration A/CN.9/264]. (n.d.). mcgill.ca Retrived from https://www.mcgill.ca/ arbitration/files/arbitration/Commentaireanalytique-en.pdf [in English].

${ }^{20}$ Sprava SES Astra AB v Ukrkosmos no. 757/34281/14-ц [Case SES Astra AB v Ukrkosmos no. 757/34281/14-ц ] (n.d.). reyestr.court.gov.ua. Retrived from http://www.reyestr.court.gov.ua/ Review/62960687 [in Ukrainian]. 
First instance court refused recognition and enforcement. Appellate court, when revoking the refusal, considered that Ukrkosmos was duly notified of the proceedings, arbitrator's appointment and even informed the tribunal of its legal representative and requested extension for presenting its case. In such circumstances, opined the appellate court, Ukrkosmos had all reasonable opportunities to present its case and, among others, to object to tribunal formation, and having failed to do so, Ukrkosmos is barred from doing it at the recognition and enforcement stage.

Cassation court, when considering the matter and the ruling of which is final and binding, did not agree with the appellate court and noted as follows: irrespective of the notification of and attorney appointing by Ukrkosmos, regard has to be given to the fact that Ukrkosmos did not file any submission on the merits of the case. Thus, Ukrkosmos cannot be considered as barred from filing objections on jurisdiction, including those related to the number of arbitrators, considering its case. Since Ukrkosmos had a right to claim inadequate tribunal formation, such argument had to be considered by the court.

In considering the formation of tribunal issue, the cassation court noted that Ukrkosmos's consent to sole arbitrator was strictly conditional upon his joint nomination by the parties. Since such joint nomination was unsuccessful, the case ought to have been referred to the panel of three judges as provided for in the contract. The cassation has therefore ruled, that the award could not be recognized and enforced, the tribunal having been formed in violation of parties arbitration agreement provisions.

One more case that may fall within the present category deals with the mandatory pre-litigation dispute settlement procedures, entered into by the parties. In the case the obligatory pre-trial settlement of a dispute, which excludes the possibility of filing a statement of claim before it is complied with, is in place, failure to observe all the steps may be treated as violation of the arbitral procedure, agreed upon by the parties.

The mandatory out-of-court dispute settlement procedures agreed upon in agreements entered into by the parties in the case Odeskyi morskyi torhivelnyi port $v$ International Port Services Ltd ${ }^{21}$. The decision rendered by the ICAC in favor of Odeskyi morskyi torhivelnyi port was set aside. The reason for the cancellation was neglect of the necessity to conduct initial pre-trial settlement negotiations as a mandatory prerequisite prior to arbitration, as it was required by the arbitral agreement of the parties. In response to the claim, the Ukrainian Court proceeded

21 Sprava "Odessa Sea Commercial Port v International Port Services Ltd case no. 6-18634св07" [Case Odessa Sea Commercial Port v International Port Services Ltd case no. 6-18634св07]. (n.d.). reyestr.court.gov.ua. Retrieved from http://www.reyestr.court.gov.ua/ Review/ 1603221 [in Ukrainian]. 
from the fact that when the arbitral tribunal adjudicated a dispute, the arbitration procedure was violated, since the fact of observance of the terms of the arbitration clause and the pre-trial settlement of the dispute was not verified by the arbitral tribunal. There was no evidence of bilateral pre-trial negotiation between the parties on the subject matter of the dispute. In the consideration of the matter, the Supreme Court of Ukraine analyzed the arbitration agreement between the parties and ruled that the negotiation was mandatory and verified that materials carried no evidence of the bilateral pre-trial negotiations.

Thus, the necessity of conducting initial pre-trial settlement negotiations, as a mandatory prerequisite prior to arbitration, was neglected. With that, the Supreme Court of Ukraine found that the arbitration procedure was not in conformity with the agreement between the parties and set aside the award.

The above-discussed case is very demonstrative because, in my opinion, there is no common strategy or procedure in the Ukrainian legal practice to solve mediation issues. The first proof to support my idea is that there is no law about mediation in Ukraine. The latest attempt of the Ukrainian parliament to vote for the bill on mediation № 3665 failed in $2019^{22}$. Thus, the main question that arises is to what extent the preliminary negotiation before the lawsuit is mandatory? To answer this question it is worth discussing an example from legal practice about mediation issues.

The Constitutional Court of Ukraine rendered the decision for pre-trial settlement of disputes known as the case Campus Cotton Club ${ }^{23}$. The Constitutional Court of Ukraine reasoned that the provisions of Art. 124 (2) of the Constitution of Ukraine must be considered in a systemic connection with other provisions of the Constitution that provide legal guarantees for everyone to protect their rights and freedoms of man and citizen by any means not prohibited by Art. 55 (5) of the Constitution of Ukraine. In the opinion of the Constitutional Court, each person has the right to freely choose any means of protecting rights and freedoms that are not prohibited by law, including judicial protection. Those provisions ensure implementation of the constitutional right to judicial protection, which right can not be restricted even under conditions of martial law or state of emergency in accordance with Art. 64 of the Ukrainian Constitution ${ }^{24}$. The Constitutional Court also stated,

${ }^{22}$ Verkhovna Rada Ukrainy [Verhovna Rada of Ukraine]. (n.d.). rada.gov.ua. Retrived from http://w1.c1.rada.gov.ua/pls/zweb2/webproc4_1?pf3511=57463 [in Ukrainian].

${ }^{23}$ Rishennia Konstytutsiinoho Sudu Ukrainy u spravi za konstytutsiinym zvernenniam Tovarystva z obmezhenoiu vidpovidalnistiu "Torhovyi Dim "Kampus Kotton klab" [Ruling of the Constitutional Court of Ukraine]. (n.d.). zakon.rada.gov.ua. Retrived from https://zakon.rada.gov.ua/laws/show/v015p710-02 [in Ukrainian].

${ }^{24}$ Konstytutsiia Ukrainy [The Constitution of Ukraine]. (n.d.) zakon. rada.gov.ua Retrived from https://zakon.rada.gov.ua/laws/show/254к/96-вр.[in Ukrainian]. 
that in the case of obligatory pre-trial settlement of a dispute, which excludes the acceptance of a statement of claim for consideration and enforcement of justice, the right of a person for judicial protection will be violated. The possibility for persons to use pre-trial settlement of disputes might be an additional method of legal defense; the purpose of such complicated clauses is clear - to provide the parties with the opportunity to resolve their dispute without unnecessary expenses related to an arbitration hearing or to reduce and accelerate an arbitration procedure by reaching a certain compromise or even to resolve the merit of the dispute. And, also, proceeding from the need to increase the level of legal protection, the state can stimulate resolution of legal disputes within the framework of pre-trial procedures, but their use is discretionary standard rather than a binding one. The right to effective judicial protection does not deprive subjects of legal relations of the possibility of pretrial settlement of disputes. This can be provided for by a civil law contract when persons voluntarily choose means of protecting their rights. Pre-trial settlement of a dispute can also take place by the will of each of the participants in the legal relationship and even in the absence of the contract regarding such kind of settlement of the dispute.

Ergo, we can conclude, that selection of a certain legal remedy, including pre-trial settlement of a dispute in Ukraine, is a dispositive right of a person who may voluntarily, based on his own interests, use it. Legal establishment of mandatory pre-trial settlement of a dispute limits the possibility of exercising the right to judicial protection. Application for arbitration is contractual and not constitutional. Consequently, there may be restrictions stipulated by the agreement (contract of the parties) only.

Despite all the difficulties with mediation in Ukraine, one, but big and definitely positive step forward towards mediation was made not that long ago. On the $7^{\text {th }}$ of August 2019 Ukraine has signed the United Nations Convention on International Settlement Agreements Resulting from Mediation, called the Singapore Convention on Mediation. Mediation is a means of dispute resolution and an alternative to the court is only beginning to grow in Ukraine. The signing of the convention will be another impetus for the adoption of the Ukrainian national law on mediation and the improvement of the whole legal system. It will encourage the use of mediation to resolve transnational disputes in international commercial arbitration. As we know, the legal validity (force) of the agreement entered into as a result of mediation is one of the crucial factors in deciding the parties of a dispute to betake mediation.

Execution of mediation agreements with an international element makes it difficult to find parties in different jurisdictions. But, the Convention, therefore, provides for the obligation of the states parties to the Convention to enforce international mediation agreements in accordance with national 
procedural law and in accordance with the conditions laid down in the Convention. If, for example, a Ukrainian company and another foreign company from a member country of the Convention has a dispute that was settled during and by means of mediation, one will only need to go to the Court for a simplified procedure for formally reviewing and recognizing such a decision and obtaining a court order for implementation.

Hence, this Convention adds guarantees of execution of the mediation and implementation of agreements that have been concluded as a result of mediation. Ukraine's participation in the signing of the Convention gives a good sign for the world international trade business, as well as, a huge step for Ukraine in recognition of the mediation process and joining the world community. Also, for the long run, it will have the effect of creating a more favorable investment climate, reducing the costs of business to settle disputes and unloading the courts.

One more issue is extremely important. It is necessary to differentiate mediation and settlement agreements. Settlement agreements can be concluded not only in the mediation process but also in the process of other peaceful methods of dispute settlement (negotiation, reconciliation), authors of the Convention stressed in the text that the Convention will be applied only to the agreements concluded as a result of mediation.

\section{The award deals with a difference not contemplated by or not falling} within the terms of the submission to arbitration or contains decisions on matters beyond the scope of submission to arbitration, provided that, where the decisions on matters submitted to arbitration can be separated

from those not so submitted, that part of the award which contains decisions on matters submitted to arbitration may be recognized and enforced

Cargill International SA $v$ LZ Group INC case was initiated under a partnership agreement concluded between companies in 2001 in accordance with the laws of England ${ }^{25}$. In 2006, a debt repayment agreement was concluded between the same parties. It is seen from the preamble of debt repayment agreement that the parties did business on the basis of the agreement concluded in 2001, out of which the indebtedness emerged. Thus, a debt repayment agreement was derived from a partnership agreement which provided for their joint business.

${ }^{25}$ Sprava "Cargill International SA v LZ Group. Inc case no. 6-4902cr12" [Case Cargill International SA v LZ Group. Inc no. 6-4902cr12]. (n.d.). reyestr.court.gov.ua. Retrieved from http://www.reyestr.court.gov.ua/Review/23930277 [in Ukrainian]. 
The debt repayment agreement specified that any dispute arising out of an existing contract had to be transferred for final settlement to the ICAC at the UCCI. Such a dispute between the parties was considered and resolved by the ICAC at the UCCI. In July 2009, LZ Group Inc. applied to the Court for setting aside the final award. The application was based upon the allegation that the decision was made with an infraction of the law, whereunder arbitral tribunals may not consider matters beyond the scope of arbitral agreement. Ukrainian Court granted the application for setting aside the award taking into account the fact that the ICAC considered the case that was not covered by an arbitration agreement between the parties.

In the above mentioned case, we can again observe, that the Court of Ukraine does not take into account the principle of the competence of the arbitral tribunal and the principle of the waiver of the right to object that we have discussed above.

\section{The award has not yet become binding on the parties, or has been set aside or suspended by a competent authority of the country in which, or under the law of which, that award was made}

Polske hurnitstvo naftove $i$ hazovnitstvo S.A. v Devon case ${ }^{26}$. Ukrainian local Court considered the evidence that had to be provided to the Court to prove the entry into force of an arbitral award. The application from the party must be accompanied by a decision of the foreign Court and an official document to the effect that the decision has come into force and is enforceable or that it is enforceable until it is legally valid unless this is evident from the decision itself in accordance with Art. 7 of the Resolution № $12^{27}$.

The arbitration award itself stated that it was final, but it did not indicate at which moment the Court's decision would come into force, and there was no any official document mentioning that the arbitral award was legally valid. Therefore, the case was transferred for a new trial to the Court of first instance in Ukraine.

${ }^{26}$ Sprava "Polske hurnitstvo naftove i hazovnitstvo S.A. v Devon" case no. 757/1469/16-ц" [Case Polske hurnitstvo naftove i hazovnitstvo S.A. v Devon no. 757/1469/16-ц] (n.d.). reyestr.court.gov.ua. Retrieved from http://www.reyestr.court.gov.ua/Review/70845941 [in Ukrainian].

${ }^{27}$ Postanova no. 12 Plenum verkhovnoho sudu Ukrainy "Pro praktyku rozghliadu sudamy klopotan pro vyznannia y vykonannia rishen inozemnykh sudiv ta arbitrazhiv i pro skasuvannia rishen, postanovlenykh u poriadku mizhnarodnoho komertsiinoho arbitrazhu na terytorii Ukrainy" [The Resolution no. 12 of the Plenum of the Supreme Court of Ukraine "On practice of consideration by courts of motions for recognition and enforcement of foreign courts' awards and arbitral tribunals' awards and on annulment of awards rendered by international commercial arbitration courts in the territory of Ukraine"]. (n.d.) zakon.rada.gov.ua Retrived from https://zakon.rada.gov.ua/laws/show/v0012700-99 [in Ukrainian]. 
The matter of binding nature of the award was also considered in the Ukrmedpostach v Vamed Engineering GmbH \& Co KG case ${ }^{28}$. The Cassation Court, considering the motion of Ukrmedpostach for recognition and enforcement of an arbitral award took into consideration, that Vamed has filed an application for setting aside of the award. At the moment of consideration by the cassation court, Vamed had obtained a ruling for setting aside of the award, in view of which recognition and enforcement in favor of Ukrmedpostach was denied.

\section{The subject matter of the difference is not capable of settlement by arbitration under the law of that country}

The matter was considered in the Ukrmedpostach v Vamed Engineering $\mathrm{GmbH} \& \mathrm{Co} \mathrm{KG}$ case cited above. The dispute between the parties arose a state owned company Ukrmedpostach and Vamed out of a contract for purchase and installation of medical equipment. The contract provided for resolution of all disputes thereunder by the ICAC at the UCCI.

Given the poor performance of obligations under the contract Ukrmedpostach filed its claims against Vamed with the ICAC at the UCCI and obtained an award in its favor. Vamed moved to set the award aside. In its setting aside application Vamed claimed, among others, that the dispute was not capable of being settled in arbitration due to its non-arbitrable nature under the Ukrainian law, which governed the contract.

The courts considered the matter and agreed with Vamed, ruling to set aside the award. In particular, the courts considered, that contract between the parties was concluded for the purposes of public needs satisfaction. As of the date of contract conclusion public needs contracts were not arbitrable under Ukrainian and could be resolved solely in the competent domestic court. Thus, the court ruled, that the dispute between the parties could not have been subjected to arbitration and thus the award could should be set aside.

\section{Recognition or enforcement of the award would be contrary to the public policy of the respective country}

The case between JKX Oil\&Gas Plc et al v Ukraine (represented by the Ministry of Justice of Ukraine $)^{29}$. An investment dispute over the failure of the

${ }^{28}$ Sprava "Ukrmedpostach v Vamed Engineering GmbH \& Co KG case no. 6-42203св14" [Case Ukrmedpostach v Vamed Engineering GmbH \& Co KG case no. 6-42203cв14] (n.d.). reyestr.court.gov.ua. Retrieved from http://www.reyestr.court.gov.ua/Review/43475034 [in Ukrainian].

${ }^{29}$ Sprava "JKX Oil\&Gas Plc et al v Ukraine case no. 757/5777/15-ц" [Case JKX Oil\&Gas Plc et al v Ukraine case no. 757/5777/15-ц] (n.d.). reyestr.court.gov.ua. Retrieved from http://www.reyestr.court.gov.ua/Review/76596637 [in Ukrainian]. 
debtor to comply with its international legal obligations under the Energy Charter Treaty (was ratified by the Verkhovna Rada of Ukraine in 1998).

The parties appealed to the Arbitration Institute of the Chamber of Commerce of Stockholm. The arbitral tribunal made a decision whereby the state of Ukraine was ordered to refrain from imposing a rent on the Poltava Petroleum Company for the use of mineral resources, for the extraction of natural gas by at a rate higher than $28 \%$, which rate was stipulated by the Ukrainian tax code of July 31, 2014. The Ministry of Justice of Ukraine, which represents the state of Ukraine in the dispute, objected to satisfaction of Poltava Petroleum Company's claim, reasoning that the arbitral award violated public order and threatened economic interests of Ukraine.

The Supreme Court found that according to the Resolution № 12 (10), the public order means the legal order of the state, basic principles, and foundations of the existing state system (related to its independence, integrity of the territory, autonomy and inviolability, basic constitutional rights, freedoms, guarantees, etc.) ${ }^{30}$. Also, in accordance with Art. 12 (1) of the Private international law (hereinafter - "On PIL"), the law of a foreign country does not apply when its application leads to consequences that are clearly incompatible with the principles of law and public order of Ukraine ${ }^{31}$.

The Supreme Court of Ukraine reasoned its decision that the relationships arising in the field of collection of taxes and mandatory charges are regulated by the Tax Code of Ukraine. The Tax Code sets out the exhaustive list of taxes and charges that are enforceable in Ukraine, the procedure for their administration, payers of taxes and charges, their rights and duties, competence of the authorities, the powers and responsibilities of their officials in the tax control, as well as responsibility for violating tax laws. In accordance with Article 7 (3) of the Tax Code of Ukraine, any taxation issues are regulated by that Code and can not be established or changed by other laws of Ukraine, except for the laws that contain provisions to amend that code and provisions that establish liability for violation of tax legislation. Only the Tax Code of Ukraine specifies the grounds for the

${ }^{30}$ Postanova no. 12 Plenum verkhovnoho sudu Ukrainy "Pro praktyku rozghliadu sudamy klopotan pro vyznannia y vykonannia rishen inozemnykh sudiv ta arbitrazhiv i pro skasuvannia rishen, postanovlenykh u poriadku mizhnarodnoho komertsiinoho arbitrazhu na terytorii Ukrainy" [The Resolution no. 12 of the Plenum of the Supreme Court of Ukraine "On practice of consideration by courts of motions for recognition and enforcement of foreign courts' awards and arbitral tribunals' awards and on annulment of awards rendered by international commercial arbitration courts in the territory of Ukraine"]. (n.d.) zakon.rada.gov.ua Retrived from https://zakon.rada.gov.ua/laws/show/v0012700-99 [in Ukrainian].

${ }^{31}$ Zakon Ukrainy "Pro mizhnarodne pryvatne pravo" [The law of Ukraine " On Private International Law”]. (n.d). zakon.rada.gov.ua. Retrived from https://zakon.rada.gov.ua/laws/ show $/ 2709-15$ ?find $=1 \&$ text $=\% \mathrm{EF} \% \mathrm{~F} 3 \% \mathrm{E} 1 \% \mathrm{~EB} \% \mathrm{~B} 3 \% \mathrm{~F} 7 \% \mathrm{ED} \% \mathrm{E} 8 \% \mathrm{E} 9$ [in Ukrainian]. 
granting of tax privileges and the procedure for their application ${ }^{32}$. The Court ruled that the arbitral award was contrary to the requirements of the Ukrainian Tax Code and could actually change the rental fees to be paid by a legal entity Poltava Petroleum Company for the use of resources to extract natural gas from $55 \%$ to $28 \%$.

The opinion of the Supreme Court was motivated by the fact that extending the competence of arbitral Courts to change the size of taxes or mandatory charges is contrary to the rules of the tax code of Ukraine and would be a violation of the basic, determined principles of taxation established in the state and by the state and, therefore, recognition and enforcement of an arbitral award violates the public order of Ukraine, and therefore, an arbitral award can not be recognized and enforced in the territory of Ukraine.

In authors opinion, on the one hand, the definition of public order in Ukraine is generalized and rather inexact, but on the other hand, the result of enforcement of the foreign arbitration award - change of the whole Ukrainian taxation system - is very vivid and obvious. Therefore, we will get the conflict of two laws in one jurisdiction: national and foreign. Thus, the very concept of public order in Ukraine means that no foreign law can compete with the norms of the national law and the latter will always prevail.

There are a number of other grounds for canceling or refusing in recognition of arbitral awards, but they probably relate to more technical issues, for example, the case between SPACE-COMMUNICATION LTD and the TV-broadcasting company "MIST $T B$ "33. The request of SPACECOMMUNICATION LTD on recognition and enforcement of the ICAC award was not signed by the person in whose favor the decision was made and I application for recognition and enforcement shall be submitted in writing and signed by the person in whose favor the decision has been made or by its representative. Such applications submitted without compliance with the requirements remain unmoved, but the deadline for the elimination of deficiencies is mentioned in Article 185 of the CPC of Ukraine. Few more reasons, it is when an arbitration agreement does not contain the exact name of the court to which the parties must refer disputes, the case "ARSLAN" and "HUAWEI"34, or when order of enforcement issued by the state court of Ukraine does not meet the requirements of the law of Ukraine.

32 Podatkovyi kodeks Ukrainy [The Tax Code of Ukraine]. (n.d.). zakon.rada.gov.ua. Retrived from https://zakon.rada.gov.ua/laws/show/2755-17 [in Ukrainian].

33 Sprava "Space-communication LTD v. MIST TB no. 22-k/796/190/18" [Case Spacecommunication LTD v. MIST TB no. 22-k/796/190/18] (n.d.). reyestr.court.gov.ua. Retrieved from http://www.reyestr.court.gov.ua/Review/76153012 [in Ukrainian].

${ }^{34}$ Sprava “Arslan v Huawei no. 910/8259/13" [Case "Arslan v Huawei no. 910/8259/13"]. (n.d.). reyestr.court.gov.ua. Retrived from http://www.reyestr.court.gov.ua/Review/33822930 [in Ukrainian]. 
Just the same as it was in the case "Metalurhiinyi zavod Dniprostal" and "DALMOND TRADE HOUSE LTD”, because order of enforcement did not contain full information about the debtor and full-resolution part of the decision of the ICAC of Ukraine, as well as it did not specify the correct date of legal validity of the award ${ }^{35}$.

\section{CONCLUSIONS}

In solving a particular case in court, we have to consider countless nuances. Legal practice is always ambiguous, diverse and complex, irrespective of the country, but we should follow those approaches or tendencies that could bring us most fruitful and predictable results.

Each arbitration-friendly jurisdiction should strictly follow the transnational rules, conventions, and other international norms, especially when dealing with grounds for annulment of international commercial arbitration awards and, of course, take into consideration their own national laws. The balance between international and national laws is very fragile, and it is very easy to cross the borderline in using norms of the national law more than it is necessary or preferring to use the norms of the domestic law rather than settled legal doctrines, rules, concepts, principles of international commercial arbitration.

As it is seen from the cases analyzed above, grounds for setting aside arbitral awards in Ukraine are set out in provisions of the NY Convention and in very specific and peculiar national norms, such as provisions of the $\mathrm{CC}$ or the CPC of Ukraine, resolutions, special juridical acts or provisions about the public order. Even the absence of the law, (e.g. the mediation law, which existence, in my understanding, as a doctrine still must be created in Ukraine) may be the ground to set aside an arbitral award. Till that time, from one side, Ukraine has constitutional norms, which do not contain any restrictions or warnings that prohibit rendering justice before an attempt of the preliminary settlement of the dispute by the parties. From the other side, one can also understand the existence of the idea that an appeal to arbitration is a contractual right of the parties, which implies its subordination to and limitedness by the terms of the arbitration clause.

We can also distinguish three dominating approaches used by judges for the cancellation of the arbitral awards in Ukraine. Although the approaches look controversial, debatable and ambiguous, they are the parts of the legal

\footnotetext{
${ }^{35}$ Sprava "Metalurhiinyi zavod Dniprostal v Dalmond Trade House LTD no. 202/4050/16-ц" [Case "Metalurhiinyi zavod Dniprostal v Dalmond Trade House LTD no. 202/4050/16-ц"] (n.d.). reyestr.court.gov.ua.Retrived from http://www.reyestr.court.gov.ua/Review/61445459 [in Ukrainian].
} 
mechanism used for annulment of arbitration awards in Ukraine. National Ukrainian Courts generally do not fully take into consideration such legal phenomena as 1) waiver of the right to object, 2) recognition of arbitral tribunal's competence, 3) conclusion of an arbitration agreement by exchanging the statement of claim and the answer to this claim. These tendencies are dominating in the Ukrainian litigation. They make a tremendous most principal impact on setting aside the arbitral awards in Ukraine and they are shaped with the influence of the Ukrainian national laws.

The percentage of the set aside arbitration awards or refusals of their recognition and enforcement in Ukraine is rather small. Among such a small number there are cancellations which seem to be very reasonable, logical and do not raise any specific questions or objections, for example, when the party was not duly informed about arbitral hearing or when the decision of the tribunal has not yet entered into force. However, there are, also, other grounds for cancellation of the arbitral awards in Ukraine. Their legal mechanisms for cancellation are based on the national legal norms and domestic law. These grounds look rather controversial not only because they exclude some arbitration very basic concepts, but also referring to the one norm of the Ukrainian law while cancelling the award, the judge does not take into consideration the fact that this norm is contrary to the other norm of the Ukrainian law while both these norms (laws) have equal legal power. Moreover, if such contradictions are accompanied by the lack of the clarity, for instance, in the definition of the public order or by the absence of the law such as mediation, thus, we will get the result absolutely incompatible with the idea of predictable legal practice.

The way out of this situation is quite easy and possible. From my perspective, judges should follow and take into consideration the norms of international law, international commercial arbitration case law, legal doctrines, and principles, rather than only national Ukrainian laws, even if the parties have chosen the Ukrainian law to be applied to the merit of the dispute. And, of course, judges dealing with the cases for annulment of arbitral awards in local Ukrainian courts must have a degree in international law and must know at least one world language, preferably English at a very high level.

The consequences of reference to and application of the national laws when cancelling arbitration awards, without taking into account transnational concepts, doctrines and the world arbitration principles and practice can result in ambiguity and, hence, can lead to unpredictable, untrustworthy and unclear practice. The latter, in its turn, will lead to loss of interest in cooperation with this jurisdiction, as well as in worsening of commercial relations.

Court practice is proven to be the key source in interpreting the current legislation. Overall analysis suggests that each of the potential obstacles in 
arbitration proceedings could be overcome given an understanding of how the mechanism of juridical logic is functioning in a state, hence, ensuring that the proceedings and, which is the most important result of it, enforcement of the arbitral award would be easy, efficient and successful.

I kept one more idea for last. The Ukrainian legal practice shows that cancellation of the arbitral awards is considered by civilian judges. It means that judges with specialization in Ukrainian domestic law must consider cases connected with private international law and transnational norms. Hence, in my belief, national judges as a minimum should know the English language and the International Commercial Arbitration case law and follow its development. But, the absence of the mediation law made workload per judge extremely heavy, as well as the existence of the language barrier, prevent them from mastering it to the required level. We can assume that the Ukrainian jurisdiction is not the only one to face these issues. A large number of other states might have the same problems as well. Thus, the best way out for Ukraine in this situation, as far as the author sees it, is to have high-skilled judges with a degree in international law and knowledge of at least one foreign world language. In this case, judges in local Ukrainian Courts will be able to deal with such category of cases more predictably and to solve them according to the world tendencies in international arbitration.

\section{SUMMARY}

This article deals with issues that are closely related to the interpretation and practical application of transnational legal norms and national legal acts in the cancellation of arbitral awards in the Ukrainian jurisdiction. Legal analysis of reasons for the cancellation of arbitral awards, as well as for the refusal to recognize and enforce them, is based on the Ukrainian legal practice and can be of considerable interest to practicing lawyers, judges, advocates, and students. This research into the Ukrainian legal practice enables us to understand the specificities of the national legislation and the extent of its consistency with theoretical and practical doctrines in the world's international arbitration. It also makes it possible to make conclusions about current tendencies (approaches) in the settled legal practice.

Over recent years, Ukraine has proven to be an arbitration-friendly jurisdiction, but still, there are cases of setting aside arbitration awards and refusing to recognize and enforce them. The idea of this article is to use examples from legal practice to reveal current peculiarities of the Ukrainian legal system, approaches to, reasoning, grounds and consequences for setting aside of arbitral awards in Ukraine; to show mechanisms of work, structure and argumentation of juridical logic behind cancelling or refusing to enforce arbitral awards in Ukraine. 


\section{REFERENCES}

1. Sait of electronic encyclopedia "The new Encyclopedia Britannica" [Sait of encyclopedia "The new Encyclopedia Britannica"]. britannica.com. Retrieved from https://www.britannica.com/topic/arbitration [in English].

2. Convention "On the Recognition and Enforcement of Foreign Arbitral Awards" [Convention "On the Recognition and Enforcement of Foreign Arbitral Awards"] (n.d.) newyorkconvention.org. Retrieved from http://www.newyorkconvention.org/list+of+contracting+states [in English].

3. Convention on the Recognition and Enforcement of Foreign Arbitral Awards, June 10, 1958. Available at: http://www.newyorkconvention.org/ list+of+contracting+states

4. Tsyvilnyi protsesualnyi kodeks Ukrainy [Ukrainian Code of Civil Procedure] (n.d.) kodeksy.com.ua. Retrieved from https://kodeksy.com.ua/ tsivil_nij_protsesual_nij_kodeks_ukraini/459.htm [in Ukrainian].

5. Zakon Ukrainy "Pro mizhnarodnyi komertsiinyi arbitrazh" [The Law of Ukraine "On International Commercial Arbitration"]. (n.d.) zakon.rada.gov.ua Retrived from https://zakon.rada.gov.ua/laws/show/400212 [in Ukrainian].

6. Sprava "LG Electronics Ukraine v Ant Yapi Sanayi Ve Ticaret Anonim Shirketi No. 761/605/17-ц" [Case LG Electronic Ukraine v Ant Yapi Sanayi Ve Ticaret Anonim Shirketi № 761/605/17-ц]. (n.d.). reyestr.court.gov.ua. Retrieved from http://www.reyestr.court.gov.ua/Review/ 70416292 [in Ukrainian].

7. Tsyvilnyi kodeks Ukrainy [The Civil Code of Ukraine]. (n.d.). zakon.rada.gov.ua. Retrived from https://zakon.rada.gov.ua/laws/show/43515 [in Ukrainian].

8. Postanova No. 12 Plenum verkhovnoho sudu Ukrainy "Pro praktyku rozghliadu sudamy klopotan pro vyznannia y vykonannia rishen inozemnykh sudiv ta arbitrazhiv i pro skasuvannia rishen, postanovlenykh u poriadku mizhnarodnoho komertsiinoho arbitrazhu na terytorii Ukrainy" [The Resolution No. 12 of the Plenum of the Supreme Court of Ukraine "On practice of consideration by courts of motions for recognition and enforcement of foreign courts' awards and arbitral tribunals' awards and on annulment of awards rendered by international commercial arbitration courts in the territory of Ukraine"]. (n.d.) zakon.rada.gov.ua Retrived from https://zakon.rada.gov.ua/laws/show/v0012700-99 [in Ukrainian].

9. Tsyvilnyi kodeks Ukrainy [The Civil Code of Ukraine]. (n.d.) zakon.rada.gov.иа Retrived from https://zakon1.rada.gov.ua/laws/show/43515/ed20120618 [in Ukrainian].

10. Zakon Ukrainy "Pro mizhnarodnyi komertsiinyi arbitrazh" [The Law of Ukraine "On International Commercial Arbitration"]. (n.d.) zakon.rada.gov.ua Retrived from https://zakon.rada.gov.ua/laws/show/400212 [in Ukrainian]. 
11. Phillip Landolt, The Inconvenience of Principle: Separability and Kompetenz-Kompetenz (2013) [The Inconvenience of Principle: Separability and Kompetez-Kompetenz] Journal of International Arbitration, (Vols 30), (pp. 511-530). The Netherlands: Kluwer Law International BV [in English].

12. Ronán Feehily, (2018). Separability in international commercial arbitration; confluence, conflict and the appropriate limitations in the development and application of the doctrine [Separability in international commercial arbitration; confluence, conflict and the appropriate limitations in the development and application of the doctrine] Arbitration International, 34. Retrived from https://academic.oup.com/arbitration/article-abstract/34/3/355/ 5098414 [in English].

13. The UNCITRAL Model Law [The UNCITRAL Model Law]. (n.d.) uncitral.un.org. Retrived from https://uncitral.un.org/en/texts/arbitration/ modellaw/commercial_arbitration [in English].

14. Sprava "Naumann Machyny i Pallety v Bruma № No. 159/4966/15-ц" [Case Naumann Machyny i Pallety v Bruma № o. 159/4966/15-ц] (n.d.). reyestr.court.gov.ua. Retrieved from http://www.reyestr.court.gov.ua/Review/ 63323683 [in Ukrainian].

15. Sprava "Sea Emerald S.A. v Sudnobudivny zavod imeni 61 comunara case No. 1423/15646/2012" [Case Sea Emerald S.A. v Sudnobudivny zavod imeni 61 comunara No. 1423/15646/2012]. (n.d.). reyestr.court.gov.ua. Retrieved from http://www.reyestr.court.gov.ua/Review/62203095 [in Ukrainian].

16. The Arbitration Act 1996 [The Arbitration Act 1996]. (n.d.). legislation.gov.uk. Retrived from https://www.legislation.gov.uk/ukpga/ 1996/23/section/76 [in English].

17. Sprava Nussed Serbia d.o.o. v Rise Company case No. 761/5425/16-ц [Case Nussed Serbia d.o.o. v Rise Company case No. 761/5425/16-ц]. (n.d.). reyestr.court.gov.ua. Retrieved from http://www.reyestr.court.gov.ua/Review/ 71534619 [in Ukrainian].

18. The ICAC at the UCCI Rules 2018 [The ICAC at the UCCI Rules 2018]. (n.d.). icac.org.ua Retrived from https://icac.org.ua/en/arbitrazh/ reglament/ [in English].

19. Reinhold, Steven, Good Faith in International Law (2013). [Good Faith in International Law] Journal of Law and Jurisprudence, 2. Retrived from https://ssrn.com/abstract=2269746 [in English].

20. Analytical Commentary on Draft Text of a Model Law on International Commercial Arbitration A/CN.9/264 [Analytical Commentary on Draft Text of a Model Law on International Commercial Arbitration A/CN.9/264]. (n.d.). mcgill.ca Retrived from https://www.mcgill.ca/arbitration/files/arbitration/ Commentaireanalytique-en.pdf [in English]. 
21. Sprava SES Astra AB v Ukrkosmos No. 757/34281/14-ц [Case SES Astra AB v Ukrkosmos No. 757/34281/14-ц] (n.d.). reyestr.court.gov.ua. Retrived from http://www.reyestr.court.gov.ua/Review/62960687 [in Ukrainian].

22. Sprava "Odessa Sea Commercial Port v International Port Services Ltd case No. 6-18634св07" [Case Odessa Sea Commercial Port v International Port Services Ltd case No. 6-18634св07]. (n.d.). reyestr.court.gov.ua. Retrieved from http://www.reyestr.court.gov.ua/Review/1603221 [in Ukrainian].

23. Verkhovna Rada Ukrainy [Verhovna Rada of Ukraine]. (n.d.). rada.gov.ua. Retrived from http://w1.c1.rada.gov.ua/pls/zweb2/webproc4_ 1?pf3511=57463 [in Ukrainian].

24. Rishennia Konstytutsiinoho Sudu Ukrainy u spravi za konstytutsiinym zvernenniam Tovarystva z obmezhenoiu vidpovidalnistiu "Torhovyi Dim "Kampus Kotton klab" [Ruling of the Constitutional Court of Ukraine]. (n.d.). zakon.rada.gov.ua. Retrived from https://zakon.rada.gov.ua/laws/show/ v015p710-02 [in Ukrainian].

25. Konstytutsiia Ukrainy [The Constitution of Ukraine]. (n.d.) zakon. rada.gov.ua Retrived from https://zakon.rada.gov.ua/laws/show/254K/96вр.[in Ukrainian].

26. Sprava "Cargill International SA v LZ Group. Inc case No. 6-4902cr12" [Case Cargill International SA v LZ Group. Inc No. 6-4902cr12]. (n.d.). reyestr.court.gov.ua. Retrieved from http://www.reyestr.court.gov.ua/ Review/23930277 [in Ukrainian].

27. Sprava "Polske hurnitstvo naftove i hazovnitstvo S.A. v Devon" case No. 757/1469/16-ц [Case Polske hurnitstvo naftove i hazovnitstvo S.A. v Devon No. 757/1469/16-ц] (n.d.). reyestr.court.gov.ua. Retrieved from http://www.reyestr.court.gov.ua/Review/70845941 [in Ukrainian].

28. Postanova No. 12 Plenum verkhovnoho sudu Ukrainy "Pro praktyku rozghliadu sudamy klopotan pro vyznannia y vykonannia rishen inozemnykh sudiv ta arbitrazhiv i pro skasuvannia rishen, postanovlenykh u poriadku mizhnarodnoho komertsiinoho arbitrazhu na terytorii Ukrainy" [The Resolution No. 12 of the Plenum of the Supreme Court of Ukraine "On practice of consideration by courts of motions for recognition and enforcement of foreign courts' awards and arbitral tribunals' awards and on annulment of awards rendered by international commercial arbitration courts in the territory of Ukraine"]. (n.d.) zakon.rada.gov.ua Retrived from https://zakon.rada.gov.ua/laws/show/v0012700-99 [in Ukrainian].

29. Sprava "Ukrmedpostach v Vamed Engineering GmbH \& Co KG case No. 6-42203 св14" [Case Ukrmedpostach v Vamed Engineering GmbH \& Co KG case No. 6-42203св14] (n.d.). reyestr.court.gov.ua. Retrieved from http://www.reyestr.court.gov.ua/Review/43475034 [in Ukrainian]. 
30. Sprava "JKX Oil\&Gas Plc et al v Ukraine case No. 757/5777/15-ц" [Case JKX Oil\&Gas Plc et al v Ukraine case No. 757/5777/15-ц] (n.d.). reyestr.court.gov.ua. Retrieved from http://www.reyestr.court.gov.ua/Review/ 76596637 [in Ukrainian].

31. Postanova No. 12 Plenum verkhovnoho sudu Ukrainy "Pro praktyku rozghliadu sudamy klopotan pro vyznannia y vykonannia rishen inozemnykh sudiv ta arbitrazhiv i pro skasuvannia rishen, postanovlenykh u poriadku mizhnarodnoho komertsiinoho arbitrazhu na terytorii Ukrainy" [The Resolution No. 12 of the Plenum of the Supreme Court of Ukraine "On practice of consideration by courts of motions for recognition and enforcement of foreign courts' awards and arbitral tribunals' awards and on annulment of awards rendered by international commercial arbitration courts in the territory of Ukraine"]. (n.d.) zakon.rada.gov.ua Retrived from https://zakon.rada.gov.ua/laws/show/v0012700-99 [in Ukrainian].

32.Zakon Ukrainy "Pro mizhnarodne pryvatne pravo" [The law of Ukraine " On Private International Law"]. (n.d). zakon.rada.gov.ua. Retrived from https://zakon.rada.gov.ua/laws/show/2709-15?find=1\&text=\%EF\%F3\% E1\%EB\%B3\%F7\%ED\%E8\%E9 [in Ukrainian].

33. Podatkovyi kodeks Ukrainy [The Tax Code of Ukraine]. (n.d.). zakon.rada.gov.ua. Retrived from https://zakon.rada.gov.ua/laws/show/ 2755-17 [in Ukrainian].

34. Sprava "Space-communication LTD v. MIST TB No. 22-k/796/190/18" [Case Space-communication LTD v. MIST TB No. 22-k/796/190/18] (n.d.). reyestr.court.gov.ua. Retrieved from http://www.reyestr.court.gov.ua/Review/ 76153012 [in Ukrainian].

35. Sprava "Arslan v Huawei No. 910/8259/13", [Case "Arslan v Huawei No. 910/8259/13”]. (n.d.). reyestr.court.gov.ua. Retrived from http://www.reyestr.court.gov.ua/Review/33822930 [in Ukrainian].

36. Sprava "Metalurhiinyi zavod Dniprostal v Dalmond Trade House LTD No. 202/4050/16-ц" [Case "Metalurhiinyi zavod Dniprostal v Dalmond Trade House LTD No. 202/4050/16-ц"] (n.d.). reyestr.court.gov.ua.Retrived from http://www.reyestr.court.gov.ua/Review/61445459 [in Ukrainian].

\section{Information about the author: \\ Yuliya Kabrera,}

Postgraduate Student,

Institute of Law, Economics and International Relations, International Humanitarian University in Odessa

33, Fountain Road str., Odessa, Ukraine ORCID ID: orcid.org/0000-0002-7357-1491 